\title{
Effect of Impacts on Human Head
}

Martin Svoboda ${ }^{1}$, Josef Soukup ${ }^{1}$, Karel Jelen², Petr Kubový

${ }^{1}$ Faculty of production technology and management Jan Evangelista Purkyně University in Ústí nad Labem, Czech Republic, Na Okraji 1001, e-mail: svoboda@fvtm.ujep.cz

${ }^{2}$ Faculty of Psychical Education and Sport Charles University, José Mártího 31, Praha 6 - Veleslavín, e-mail: kubovy@ftvs.cuni.cz

The article deals with experimental measurements of force effects that direct blow develops taekwondo sportsman. Power effects are captured using a high speed camera. Experimental measurements have confirmed the results of many scientific papers that deal with the measurement of the force effects of combat sports athletes, etc. There are described some methods that are used in medicine and biomechanics to view internal organs or injury detection.

Keywords: biomechanics, impact, deformation, measurement, human head

\section{Literature}

[1] ARASH, A., S., EFTYCHIOS, CH., BENJAMIN, Z., GUY, M., G., PHILIP, V., B. (2008). Deformation of the human brain induced by mild angular head acceleration, Journal of Biomechanics, 41, p. 307-315

[2] PARSHURAM, P., GHODRAT, K., MARIUSZ, Z. (2011). Examination of brain injury under impact with the ground of various stiffness, Procedia Engineering, 13, 2011, p. 409-414

[3] PINTAR, A., F., PHILIPPENS, M., ZHANG, Y., J., YOGANANDAN, N. (2013). Methodology to determine skull bone and brain responses from ballistic helmet-to-head contact loading using experiments and finite element analysis, Medical Engineering \& Physics, 35, p. 1682- 1687

[4] WALILKO T. J., VIANO D. C., BIR C. A., Biomechanics head in response to blows to the face carried the Olympic boxers, Br J Sports Med 2005;39:710-719. doi: 10.1136/bjsm.2004.014126

[5] aviable at: <http://www.extraround.cz/cs/clanek/rozhovor-s-hlavnim-doktorem-studie-mozkovych-traumat-vboxu-a-mma-?cid=1500> , retrived on August 42014

[6] NAHUM A. M., GATTS J. D., GADD C. W., AND DANFORTH J. P. (1968). Impact tolerance of the skull and face. In 2th STAPP Car Crash Conference Proceedings, no. 680785. SAE, pp. 302-316.

[7] SCHNEIDER D. C., NAHUM A. M. (1972). Impact studies of facial bones and skull. In 16th STAPP Car Crash Conference Proceedings. SAE Society of Automotive Engineers, p. 186.

[8] HOPPER R. H., MCELHANEY J. H., MYERS B. S. (1994). Mandibular and basilar skull fracture tolerance. In 38th STAPP Car Crash Conference Proceedings. SAE Society of Automotive Engineers, 1994.

[9] NYQUIST G. W., CAVANAUGH J. M., GOLDBERG S. J., KING A. I. (1986). Facial impact tolerance and response. In Proc. 30th Stapp, no. 861896. SAE, October, p. 189.

[10]ALLSOP D. L., WARNER C. Y., WILLE M. G., SCHNEIDER D. C., NAHUM A. M. (1988). Facial impact response comparison of the hybrid iii dummy and human cadaver. In Proc. 32th Stapp, no. 881719. SAE, October, p. 139.

[11] ALLSOP D. L. (1989). Human facial fracture and compliance. Ph.D. dissertation, Department of Mechanical Engineering, Brigham Young University.

[12] NAHUM A. M., WARD C. C., RAASCH F. O., ADAMS S., SCHNEIDER D. C. (1980). Experimental studies of side impact to the human head. In 24th STAPP Car Crash Conference Proceedings. SAE Society of Automotive Engineers.

[13]NAHUM A. M., WARD C. C., SCHNEIDER D. C., RAASCH F. O., ADAMS S. (1981). A study of impacts to the lateral protected and unprotected head. In 25th STAPP Car Crash Conference Proceedings. SAE Society of Automotive Engineers.

[14] STALNAKER R. L., ROBERTS V. L., MCELHANEY J. H. (1973). A study of impacts to the lateral protected and unprotected head. In 17th STAPP Car Crash Conference Proceedings. SAE Society of Automotive Engineers.

[15]GOT C., PATEL A., FAYON A., TARRIERE C., WALFISCH G. (1978). Results of experimental head impacts on cadavers: the various data obtained and their relations to some measured physical parameters. In 22th STAPP Car Crash Conference Proceedings. SAE Society of Automotive Engineers. 
[16] OMMAYA A. K, GOLDSMITH W., THIBAULT L. (2002). Biomechanics and neuropathology of adult and paediatric head injury. review. Br J Neurosurg;16(3):220-42.

[17] PELLMAN E. J., VIANO D. C., TUCKER A. M., et al. (2003). Concussion in professional football: reconstruction of game impacts and injuries. Neurosurgery, p. 799-812.

[18]PELLMAN EJ, VIANO DC, TUCKER A. M, et al. (2003). Concussion in professional football: location and direction of helmet impacts - part 2. Neurosurgery; p. 1328-41.

[19] TREBUŇA F., HAGARA M. (20014). Ehagara, Measurement, 50(4), pp 78-85.

[20]HAGARA M., SCHRÖTTER M., LENGVARSKÝ P. (2014). An investigation of the temperature influence on a shift of natural frequencies using digital image correlation, Applied Mechanics and Materials, Vol. 611, pp 506510 .

[21]HUŇADY R., HAGARA M., SCHRÖTTER M. (2012). Using High-speed Digital Image Correlation to Determine the Damping Ratio, Procedia Engineering, Vol. 48, ISSN 1877-7058, pp 242-249. 